\title{
Feeding ecology of the white seabream, Diplodus sargus, and the ballan wrasse, Labrus bergylta, in the Azores
}

\author{
Miguel Figueiredo $^{\text {a }}$, Telmo Morato ${ }^{\mathrm{a}, *}$, João P. Barreiros ${ }^{\mathrm{b}}$, \\ Pedro Afonso ${ }^{\text {a }}$, Ricardo S. Santos ${ }^{\text {a }}$ \\ a Departamento de Oceanografia e Pescas, Universidade dos Açores, 9901-862 Horta, Portugal \\ ${ }^{\mathrm{b}}$ Departamento de Ciências Agrárias, Universidade dos Açores, 9701-851 Angra do Heroísmo, Portugal
}

Received 12 November 2003; received in revised form 31 March 2005; accepted 20 April 2005

\begin{abstract}
To make a first approach in the assessment of the sea urchin predators in the Azores, the diet of white seabream (Diplodus sargus) and ballan wrasse (Labrus bergylta), were studied by the analyses of their stomach contents. The white seabream is a diurnal omnivore, feeding on algae, sea-urchins, worms, gastropods and amphipods, while ballan wrasse fed mainly on echinoderms (sea-urchins), gastropods and decapods. Both species tended to feed on harder prey, such as echinoderms and gastropods, as they grew. Although both species feed upon similar resources, the diet overlap was low. This study shows that the white seabream and the ballan wrasse are important predators of sea-urchins in Azorean coastal habitats. Furthermore, larger fish account for most of the predation on sea-urchins. Thus, a reduction in the abundance and mean size of fishes, which is a typical consequence of fishing, may significantly decrease predation on sea-urchins and could thus facilitate their proliferation. (C) 2005 Elsevier B.V. All rights reserved.
\end{abstract}

Keywords: Feeding ecology; Diet; Trophic cascade; Sea-urchin; Azores fishery; White seabream; Diplodus sargus; Ballan wrasse; Labrus bergylta

\section{Introduction}

The of role predators in controlling populations of species in lower trophic levels has been long seen as a major structuring factor in benthic marine communities (Shears and Babcock, 2002). If a major shift in this balance occurs, for example as a result of intensive harvest

\footnotetext{
* Corresponding author. Tel.: +351292200 400; fax: +351292200411.

E-mail address: telmo@notes.horta.uac.pt (T. Morato).
}

of predatory fish, a subsequent population destabilization in lower levels (primary consumers, macroalgae) is to be expected via trophic interactions in a process known as trophic cascade (Polis et al., 2000). Because ecological interactions and population dynamics are typically more complex and unpredictable than classical predator-prey models, such shifts might further stabilize systems in an alternate state (Estes and Duggins, 1995).

An example of trophic cascades is the sea urchinbased cascade, which has recently attracted attention 
from investigators in coastal areas of temperate regions (Sala et al., 1998a; Pinnegar et al., 2000; Shears and Babcock, 2002, 2003). These studies concluded that the fisheries-related decline of predatory fish that are important sea urchin predators was responsible for subsequent increases in sea urchin populations, which by overgrazing then led to the reduction in erect algal assemblages and their subsequent substitution by crustose corallines (Sala and Zabala, 1996; Shears and Babcock, 2002). In addition, a negative feedback mechanism might have contributed to prevent local recovery of predator populations: once a population of sea urchins has developed and established itself, food resources for fish that also eat algae and epifauna can drop below the minimum threshold necessary for population development (McClanahan and Sala, 1997). Therefore, knowledge of the dynamics of these sea urchin cascades is very important for fisheriesor conservation-based management of coastal ecosystems.

In oceanic islands, trophic cascade events are likely to result in fast and dramatic changes in benthic communities due to the reduced availability of coastal habitats and to their reduced diversity (Lloris et al., 1991; Briggs, 1995) that potentially magnifies interspecific trophic relationships. This was most probably the case in Madeira Island, where a drastic reduction in sedentary coastal fish due to heavy fishing has preceded an outbreak of sea urchins and the permanent scarceness of erect algal assemblages in the shallower strata (Alves et al., 2001). Unfortunately, there are no studies directly addressing this question. In the Azores there are no sea-urchin cascades reported to date. Yet, its benthic community structure presents high similarity with Madeira, Canaries and, to a lesser extent, the Mediterranean (Lloris et al., 1991; Briggs, 1995; Santos et al., 1995). Sea-urchins are locally abundant and among the most important invertebrate grazers in shallow communities and most probably compete for resources with other grazers, including commercially important species such as parrotfish and limpets (Gonçalves, personal communication). Furthermore, there was an increase in fishing pressure over local coastal fish in the last two decades (Santos et al., 1995; Fontes et al., 2002). These records indicate that sea-urchins may be key species in the benthic community, and that seaurchin based cascades may occur in the Azores. This requires: (i) identifying the major sea-urchin preda- tors especially amongst vulnerable species; (ii) verifying the keystone role of sea-urchins by grazing macroalgae beds; (iii) quantifying the trophic dynamics of the cascade. This paper focuses on the first objective.

In the Mediterranean Sea, sparids (mainly Diplodus sargus, Linnaeus 1758) and labrids are the major predators of sea urchins therefore playing a major role in controlling their abundance and effects on benthic communities (Sala and Zabala, 1996; Sala, 1997). The white seabream (D. sargus) and the ballan wrasse (Labrus bergylta Ascanius 1767), two of the most locally common benthic dwellers in the islands (unpublished data ${ }^{1}$ ), are known to feed heavily on benthic invertebrates in other areas (Quignard, 1966; Voss, 1975; Dipper et al., 1977; Joubert and Hanekon, 1980; Rosecchi, 1985; Coetzee, 1986; Michel et al., 1987; Mann and Buxton, 1992; Deady and Fives, 1995; Sala and Ballesteros, 1997), and the white seabream was even the most important species involved in the Mediterranean sea-urchin cascade (Sala and Zabala, 1996; Sala, 1997). These two species are targeted by the coastal artisanal fishery, and a recent increase in exports of coastal species suggest a possible increase in their captures. Hence, these two species are good candidates for sea-urchin feeders and controllers.

The specific purpose of this study was to examine the diet of white seabream and ballan wrasse, and analyse their phenological and ontogenetic variations. Additionally, this study aims to examine the diet overlap between these two species. This information is then used to discuss their effect in sea-urchins and benthic communities.

\section{Material and methods}

\subsection{Sampling}

White seabream and ballan wrasse were collected by spearfishing in shallow (up to $40 \mathrm{~m}$ depth) coastal areas of Faial Island (Fig. 1), Azores. This method allows a more precise selection of individuals and minimizes regurgitation of stomach contents, which can be an important shortcoming. Disrupted stomachs were discarded.

\footnotetext{
1 Afonso (2001).
} 


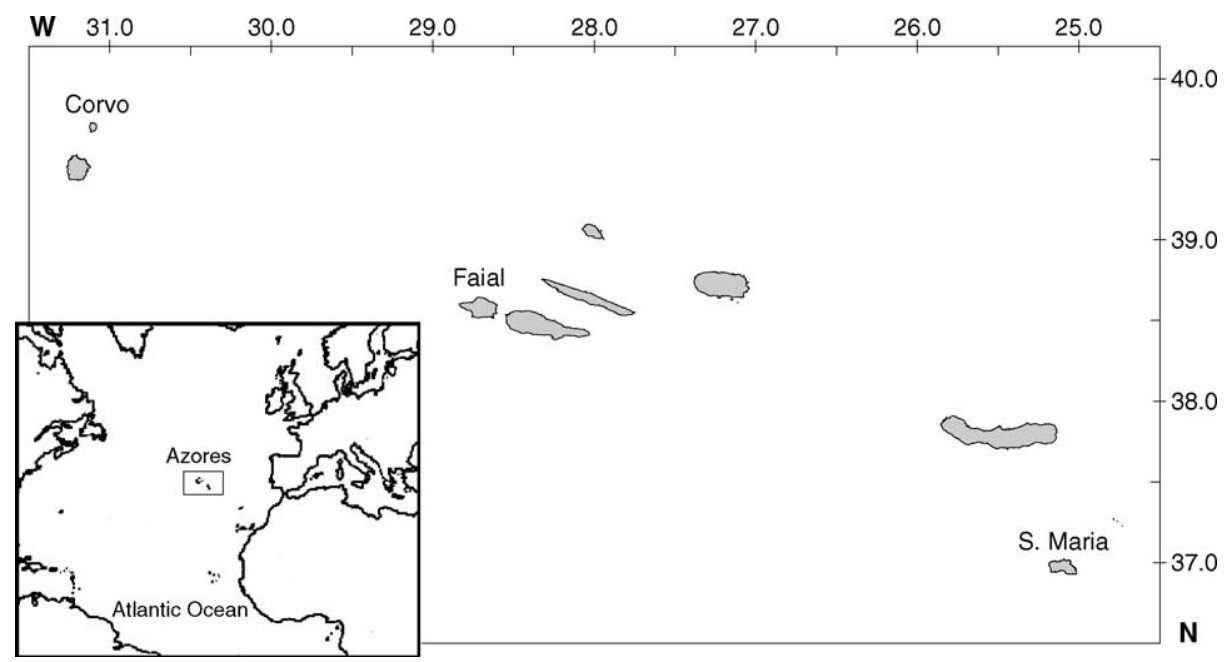

Fig. 1. Location of the Azores archipelago showing the island of Faial where sampling took place.

General sampling was undertaken from August 1997 to 1998 to study the feeding habits of both species, including their seasonal and ontogenetic changes $(n=287$ for white seabream; $n=214$ for ballan wrasse); all of these collections were made at daytime. Additional collections were made from November 1998 to February 1999 to study diel changes in the feeding activity of the white seabream $(n=155)$.

Fish were measured (SL to the nearest $\mathrm{mm}$ ), weighed and sexed macroscopically (Morato et al., 2003a for white seabream). Stomachs of white seabream were removed by cutting the esophagus near the mouth cavity and the intestine in the area anterior to the pyloric caeca, whereas in the ballan wrasse the whole digestive tract was removed, since these species do not show morphological or chemical differentiation of the stomach (Quignard, 1966). Collected material was preserved in $70^{\circ}$ alcohol. Fish ranged in size from 4.9 to $32.9 \mathrm{~cm}$ in SL (mean 19.2; S.D. $=6.4$ ) for the white seabream and from 14.1 to $38.8 \mathrm{~cm}$ SL (mean 26.9; S.D. =6.7) for the ballan wrasse.

\subsection{Diet analyses}

Stomach contents were analysed macroscopically and identified to the lowest possible taxonomic level, depending on the type and digestion level of each prey item. The wet weight of each item was registered after superficial drying with absorbing paper.

Precision estimates in diet studies have been advocated and used by several authors (Ferry and Cailliet, 1996; Morato et al., 2001a; Morato et al., 2003b). In order to evaluate sufficiency of sample size we used the pooled quadrat method (Pielou, 1966; Hurtubia, 1973; Pierce and Boyle, 1991), where the cumulative numbers of randomly pooled stomachs were plotted against the cumulative diversity. The Shannon index (Magurran, 1988) was employed to measured trophic diversity [as $H^{\prime}=-\sum_{i=1}^{n} P_{i}\left(\log _{\mathrm{e}} P_{i}\right)$, where $P_{i}$ is the proportion of individuals in the $i$ th species]. Because the cumulative diversity curves are based on random orders of quadrats, 1000 random orders of stomachs or digestive tracts for each sample were calculated. The mean curve for each sample was then estimated and plotted. Each diversity curve was considered asymptotic if at least two previous values to the total sample trophic diversity $\left(H^{\prime}\right)$ were in the range $H^{\prime} \pm 0.05 H^{\prime}$ (Alonso et al., 2002).

For each identified taxa, the following indices were calculated: percentage of occurrence $\left(\% \mathrm{O}_{i} ;\right.$ Mohan and Sankaran, 1988),

$$
\% O_{i}=\frac{n_{i}}{\sum_{i=1}^{i=n} n_{i}} \times 100,
$$


where $n_{i}$ is the number of fish in which item $i$ occurs; percentage of weight $\left(\% W_{i}\right)$,

$\% W_{i}=\frac{W_{i}}{\sum_{i=1}^{i=n} W_{i}} \times 100$,

where $W_{i}$ is the weight of item $i ; \sum_{i=1}^{i=n} W_{i}$ is the aggregated weight of all items; the Weighted Resultant Index $\left(\% R_{\mathrm{w}} ;\right.$ Mohan and Sankaran, 1988),

$\% R_{\mathrm{w}}=\frac{Q \sqrt{\% W_{i}^{2}+\% O_{i}^{2}}}{\sum Q \sqrt{\% W_{i}^{2}+\% O_{i}^{2}}} \times 100$,

where

$Q=\frac{45-|\theta-45|}{45}$

and

$\theta=\tan ^{-1}\left(\frac{O_{i}}{W_{i}}\right)$

Variation of feeding intensity throughout the year was evaluated through the repletion index (RI), including empty stomachs:

$R I=\frac{\sum_{i=1}^{i=n} W_{i \mathrm{f}}}{W_{\mathrm{f}}}$

where, $W_{\mathrm{f}}$ is the total weight of the fish $f$ while $\sum W_{i \mathrm{f}}$ is the aggregate weight of all food items in the stomach of fish $f$ and vacuity coefficient (VC).

$\mathrm{VC}=\frac{\text { no. of empty stomachs }}{\text { total no. of stomachs }}$

\subsection{Seasonal changes}

Seasonal changes in the diet and in feeding activity were analyzed by partitioning the sample into five periods: summer 1997 (only for white seabream); autumn 1997; winter 1997/1998; spring 1998; summer 1998.

\subsection{Ontogenetic changes}

Ontogenetic diet changes were evaluated in two phases. First, an agglomerative hierarchical group analysis was made to generate a dendrogram based on a dissimilarity matrix for several size classes. Dissimilarity values were obtained by subtracting to 1 the Schoener's index $\left(R_{\mathrm{o}}\right)$ value (Eq. (8)), previously calculated with
$\% R_{\mathrm{W}}$ values from all food items. Grouping was made with the Unweighted Pair Group Method with Arithmetic mean (UPGMA). New coherent groupings of size classes were then identified in this exploratory dendrograms and their diet analysed as described above.

\subsection{Diel feeding intensity}

Diel feeding periodicity was examined from November 1998 to February 1999 (to reduce influence of photoperiod in the analysis) and assessed by calculating the vacuity coefficient and the repletion index. Sampling was performed in eight collection periods on a 24-h basis: 00:30-01:30 $(n=9), 03: 30-04: 30$ $(n=17)$; 06:30-07:30 $(n=18) ; 09: 30-10: 30 \quad(n=16)$; $12: 30-13: 30 \quad(n=24) ; \quad 15: 30-16: 30 \quad(n=22)$; 18:30-19:30 $\quad(n=31) ; \quad 21: 30-22: 30 \quad(n=18)$. To stop digestion process $70^{\circ}$ alcohol was injected in the stomachs immediately after capture.

\subsection{Diet overlap}

Diet overlap between the two species was evaluated by the Schoener Index, $R_{\mathrm{O}}$ (Schoener, 1970) based on $\% R_{\mathrm{w}}$ values from all food items:

$R_{\mathrm{O}}=1-0.5 \times \sum_{i=1}^{i=n}\left|p_{x i}-p_{y i}\right|$

in which, $p_{x i}$ and $p_{y i}$ are the proportions $\left(\% R_{\mathrm{w}} / 100\right)$ of item $i$ in species $x$ and $y$.

\subsection{Statistical analysis}

Non-parametric one-way analysis of variance (Kruskal-Wallis test $-H_{(\text {d.f., } N)}$ ) (Zar, 1996) was used to examine feeding activity represented by the repletion index by season, diel sampling period and size classes. Different items were grouped in larger categories according to taxonomic, structural and habitat affinities. All indices $\left(\% R_{\mathrm{w}}, \% W, \% O\right)$ were calculated for these categories by summing each item's partial values (Cortés, 1997). Category "miscellaneous" represents organisms whose $\% R_{\mathrm{w}}$ values were small and whose grouping was not possible with criteria above defined. Polychaeta, Sipuncula, Nematoda and Nemertinae were grouped in a category named "worms". Diet composition between distinct periods 
was compared by the Spearman Coefficient (Fritz, 1974 ) using the $\% R_{\mathrm{w}}$ index for ranking grouped items. Non-identified food items, sediment, paper and fish scales were excluded from the analysis. Indices $\left(\% R_{\mathrm{w}}\right.$, $\% W, \% O$ ) were then re-calculated to sum $100 \%$.

\section{Results}

\subsection{Diet of white seabream}

The diet of white seabream consisted of a wide variety of items, dominated by algae and benthic invertebrates (Table 1). Algae were clearly the most consumed item scoring the highest values of $\% R_{\mathrm{w}}, \% W$ and $\% O$. Echinodermata were second, being mostly composed by sea urchins Arbacia lixula, Sphaerechinus granularis and Paracentrotus lividus. Barnacles, especially from the family Verrucidae, were the third most important prey group. Worms were frequently consumed $(\% O)$ and were the fourth most important prey group. Gastropods, mainly from the sub-class Prosobranchia, were also important in the diet of the white seabream and included species such as Patella sp., Ocinebrina aciculate, Jujubinus pseudogravinae and Bittium sp. Fish eggs, amphipods, gastropods, fish, tunicates, decapods, bivalves and other invertebrates were also preyed by the white seabream but at lower levels.

\subsection{Diet of ballan wrasse}

Food items found in the digestive tracts of ballan wrasses are presented in Table 1. Ballan wrasse preyed upon a great variety of benthic invertebrates. Decapods, mainly true crabs (Brachyura), were the most important food items accounting for $26.7 \%$ by weight of all identified food items. Amongst decapods the most important species were Xantho incisus, Percnon gibbesi and Scyllarus arctus. Echinoderms, especially the Echinoidea were the second most important prey group accounting for $45.1 \%$ by weight of all identified food items. The sea-urchins, A. lixula, $P$. lividus and $S$. granularis were the most important echinoderms in the diet of the ballan wrasse. Gastropods were the third most important prey group occurring in $27.5 \%$ of the examined guts. Columbella adansoni, Haliotis sp., Calliostoma lusitanicum and Nassarius incrassatus, were the most important gastropod species. Algae, bivalves, worms and other invertebrates were also preyed by the ballan wrasse but at lesser extent.

Table 1

Diet composition of white seabream ( $n=207$; stomachs with contents), Diplodus sargus, and ballan wrasse ( $n=158$; stomachs with contents), Labrus bergylta, from the Azores

\begin{tabular}{|c|c|c|c|c|c|c|}
\hline \multirow[t]{2}{*}{ Food items } & \multicolumn{3}{|c|}{ White seabream } & \multicolumn{3}{|c|}{ Ballan wrasse } \\
\hline & $\% W$ & $\% O$ & $\% R_{\mathrm{W}}$ & $\% W$ & $\% O$ & $\% R_{\mathrm{W}}$ \\
\hline Algae & 44.21 & 18.42 & 38.56 & 2.26 & 6.75 & 4.86 \\
\hline Porifera & 1.36 & 0.53 & 1.11 & & & \\
\hline Cnidaria & 0.27 & 3.07 & 0.55 & 0.02 & 1.24 & 0.04 \\
\hline "Worms" & 2.17 & 12.95 & 4.43 & 0.58 & 5.53 & 1.21 \\
\hline Maxillopoda & 3.11 & 3.48 & 5.27 & 0.01 & 0.29 & 0.01 \\
\hline Amphipoda & 2.02 & 8.40 & 3.08 & 0.13 & 3.20 & 0.26 \\
\hline Isopoda & 0.03 & 1.73 & 0.09 & 0.10 & 0.72 & 0.21 \\
\hline Decapoda & 3.42 & 3.46 & 1.84 & 26.71 & 23.45 & 31.62 \\
\hline Mollusca & 10.49 & 0.80 & 1.63 & 2.18 & 0.65 & 1.37 \\
\hline Gastropoda & 1.62 & 12.00 & 3.36 & 11.14 & 27.54 & 20.45 \\
\hline Bivalvia & 2.24 & 2.66 & 1.83 & 1.47 & 7.18 & 3.11 \\
\hline Echinodermata & 9.02 & 7.47 & 5.57 & 45.07 & 12.12 & 23.11 \\
\hline Tunicata & 0.87 & 1.06 & 1.95 & & & \\
\hline Pisces & 1.31 & 1.19 & 2.11 & 0.09 & 0.15 & 0.19 \\
\hline Fish eggs & 1.51 & 2.00 & 3.29 & & & \\
\hline Miscellaneous & 0.16 & 3.59 & 0.36 & 0.22 & 2.97 & 0.46 \\
\hline
\end{tabular}

Values of percent of weight $(\% \mathrm{~W})$, frequency of occurrence $(\% O)$, and weighted resultant index $\left(\% R_{\mathrm{W}}\right)$ for each food item are presented. Full description of the diet composition is available at: http://www.horta.uac.pt/ppl/tmorato/pdf/SM_Figueiredo_etal.pdf. 

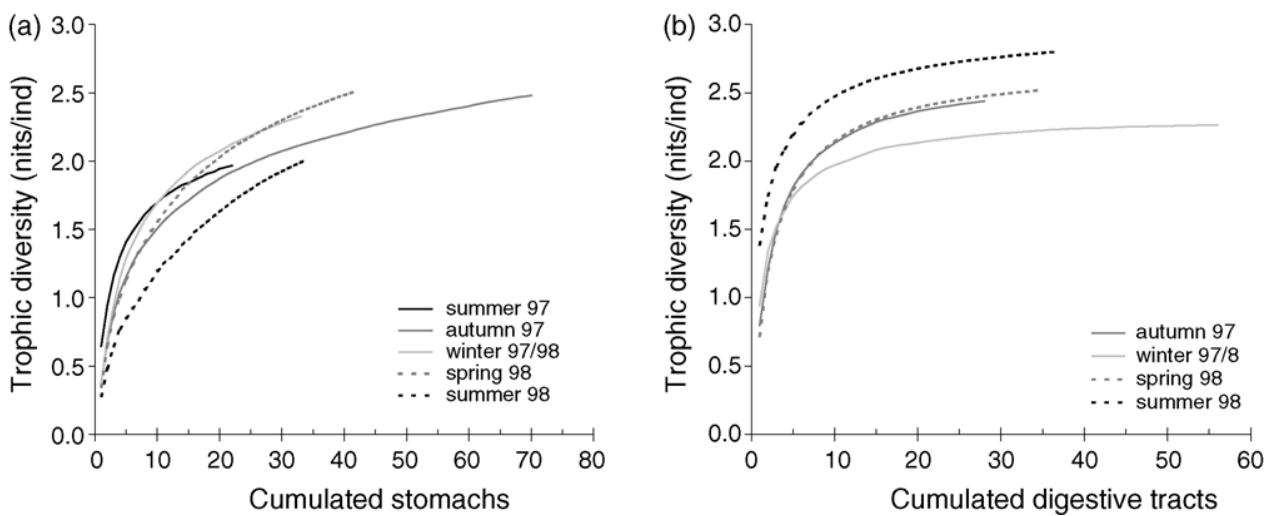

Fig. 2. Cumulative trophic diversity curves for each sampling period. (a) White seabream, Diplodus sargus and (b) ballan wrasse, Labrus bergylta. Each graph shows the mean curve from the 1000 curves obtained for each trophic group.

\subsection{Seasonal diet changes}

The number of stomachs examined to study seasonal trends in the feeding habits of white seabream appears sufficient for every seasonal period, with curves reaching an asymptote at 20-30 stomachs (Fig. 2a). Sufficient sample size was also observed for ballan wrasse, since all the curves reached an asymptote at about 30 stomachs (Fig. 2b).

Feeding intensity as evaluated with the repletion index was relatively low for both species. For white seabream it remained between 0.21 and 0.36 (RI as $\%$ of fish body weight), with the exception of the winter $1997 / 1998$ period $(\mathrm{RI}=0.45 \%)$, while for ballan wrasse it was approximately $0.6 \%$ during the whole study period. Despite these small differences between studied periods, there were no overall seasonal significant differences in the repletion index throughout the year both for white seabream and for (Kruskal-Wallis $H_{(4,206)}=3.15 ; p=0.53$ ) and for ballan wrasse (Kruskal-Wallis $H_{(3,158)}=4.47 ; p=0.21$ ).

The diet composition of white seabream varied substantially throughout the year. It was possible to identify three different periods in their feeding habits (Table 2): (i) summer of 1997 and 1998; (ii) autumn 1997 and winter 1998; (iii) spring 1998. White seabreams mostly consumed algae in every season (Table 3). Besides algae, the white seabream preys mainly on worms and amphipods during the summer, on echinoderms and gastropods during the autumn and winter, while during the spring it feeds almost exclusively on algae. Echinoderms (sea-urchins) were

Table 2

Spearman rank correlations for the diet of white seabream, Diplodus sargus and ballan wrasse, Labrus bergylta, between months

\begin{tabular}{|c|c|c|c|c|c|}
\hline & Summer 1997 & Autumn 1997 & Winter 1997/1998 & Spring 1998 & Summer 1998 \\
\hline \multicolumn{6}{|l|}{ White seabream } \\
\hline Summer 1997 & 1 & & & & \\
\hline Autumn 1997 & 0.08 & 1 & & & \\
\hline Winter 1997/1998 & 0.30 & $0.61^{*}$ & 1 & & \\
\hline Spring 1998 & 0.44 & 0.27 & 0.30 & 1 & \\
\hline Summer 1998 & $0.66^{*}$ & 0.13 & 0.48 & 0.36 & 1 \\
\hline \multicolumn{6}{|l|}{ Ballan wrasse } \\
\hline Autumn 1997 & & 1 & & & \\
\hline Winter 1997/1998 & & $0.94^{*}$ & 1 & & \\
\hline Spring 1998 & & $0.87^{*}$ & $0.92^{*}$ & 1 & \\
\hline Summer 1998 & & $0.84^{*}$ & $0.88^{*}$ & $0.97^{*}$ & 1 \\
\hline
\end{tabular}

\footnotetext{
* $p<0.05$.
} 
Table 3

Seasonal variation in the weighted resultant index $\left(\% R_{\mathrm{w}}\right)$ for white seabream, Diplodus sargus, and ballan wrasse, Labrus bergylta, from the Azores

\begin{tabular}{|c|c|c|c|c|c|c|c|c|c|}
\hline \multirow[t]{2}{*}{ Food Items } & \multicolumn{5}{|c|}{ White seabream } & \multicolumn{4}{|c|}{ Ballan wrasse } \\
\hline & $\begin{array}{l}\text { Summer } \\
1997\end{array}$ & $\begin{array}{l}\text { Autumn } \\
1997\end{array}$ & $\begin{array}{l}\text { Winter } \\
1997 / 1998\end{array}$ & $\begin{array}{l}\text { Spring } \\
1998\end{array}$ & $\begin{array}{l}\text { Summer } \\
1998\end{array}$ & $\begin{array}{l}\text { Autumn } \\
1997\end{array}$ & $\begin{array}{l}\text { Winter } \\
1997 / 1998\end{array}$ & $\begin{array}{l}\text { Spring } \\
1998\end{array}$ & $\begin{array}{l}\text { Summer } \\
1998\end{array}$ \\
\hline Algae & 35.87 & 54.77 & 54.91 & 74.32 & 45.93 & 2.21 & 1.67 & 2.11 & 14.43 \\
\hline Porifera & 0.00 & 2.39 & 0.00 & 4.72 & 0.00 & & & & \\
\hline Cnidaria & 0.00 & 1.38 & 0.82 & 0.32 & 0.35 & 0.06 & 0.07 & 0.00 & 0.07 \\
\hline "Worms" & 27.13 & 4.00 & 3.64 & 5.37 & 8.40 & 0.50 & 1.12 & 0.66 & 2.75 \\
\hline Maxillopoda & 0.00 & 6.31 & 11.69 & 0.82 & 0.84 & 0.00 & 0.05 & 0.00 & 0.00 \\
\hline Amphipoda & 20.69 & 0.19 & 0.44 & 0.33 & 11.83 & 0.03 & 0.29 & 0.61 & 0.35 \\
\hline Isopoda & 0.85 & 0.05 & 0.10 & 0.05 & 0.09 & 1.34 & 0.13 & 0.07 & 0.03 \\
\hline Decapoda & 7.44 & 3.23 & 2.04 & 2.38 & 1.15 & 26.07 & 32.65 & 41.38 & 35.71 \\
\hline Gastropoda & 0.68 & 2.70 & 11.95 & 4.58 & 0.92 & 30.92 & 19.10 & 25.31 & 19.47 \\
\hline Bivalvia & 2.57 & 2.43 & 0.00 & 2.33 & 0.28 & 9.52 & 2.99 & 0.95 & 4.10 \\
\hline Echinodermata & 3.71 & 12.77 & 10.39 & 1.02 & 7.08 & 27.38 & 39.69 & 26.75 & 19.77 \\
\hline Pisces & 0.00 & 4.67 & 1.11 & 1.13 & 0.34 & 0.00 & 0.00 & 0.30 & 0.56 \\
\hline Fish eggs & 0.07 & 0.23 & 0.04 & 1.14 & 14.73 & & & & \\
\hline Tunicata & 0.00 & 4.75 & 0.74 & 0.19 & 0.14 & & & & \\
\hline Miscellaneous & 0.99 & 0.15 & 2.12 & 1.31 & 7.93 & 1.96 & 2.25 & 1.87 & 2.74 \\
\hline$n$ & 22 & 71 & 34 & 34 & 46 & 28 & 57 & 36 & 37 \\
\hline
\end{tabular}

$n$ is the number stomachs with contents.

preyed during the whole year but were more important (in terms of $\% R_{\mathrm{w}}$ ) to the diet of white seabream during autumn and winter.

The diet of ballan wrasse was extremely uniform throughout the year. Every pairwise comparisons between seasons showed high degree of correlation (Table 2). Decapods, echinoderms and gastropods were the most important food items for the whole period (Table 3), yet showing small differences in the $\% R_{\mathrm{w}}$ index between seasons. Similarly to the white seabream, echinoderms were more important (in terms of

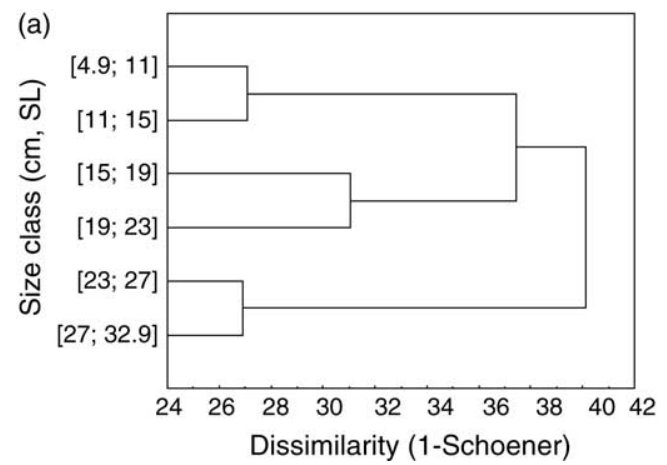

$\% R_{\mathrm{w}}$ ) to the diet of ballan wrasse during autumn and winter.

\subsection{Ontogenetic diet changes}

Preliminary analyses of ontogenetic variations in the diet composition are presented in Fig. 3. For white seabream it separated three groups to a dissimilarity level of 32\% (Fig. 3a): small, included individuals between 4.9 and $15 \mathrm{~cm} \mathrm{SL}$; medium, from 15.1 to $23.0 \mathrm{~cm} \mathrm{SL}$; and large, from 23.1 to $32.9 \mathrm{~cm} \mathrm{SL}$. For

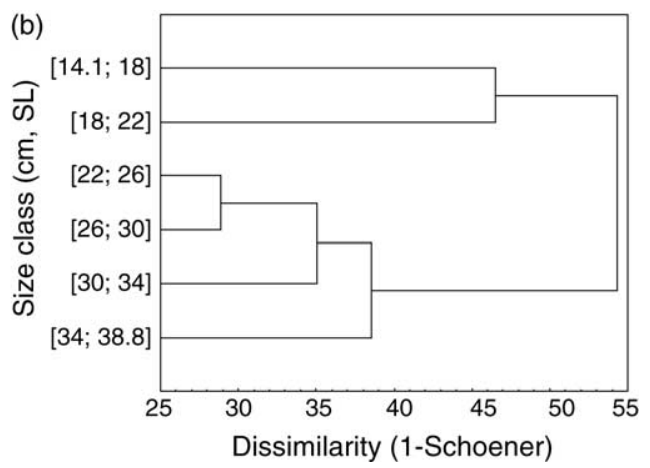

Fig. 3. Dendogram of the cluster analysis for ontogenetic patterns of feeding habits of: (a) white seabream, Diplodus sargus and (b) ballan wrasse, Labrus bergylta, from the Azores. 

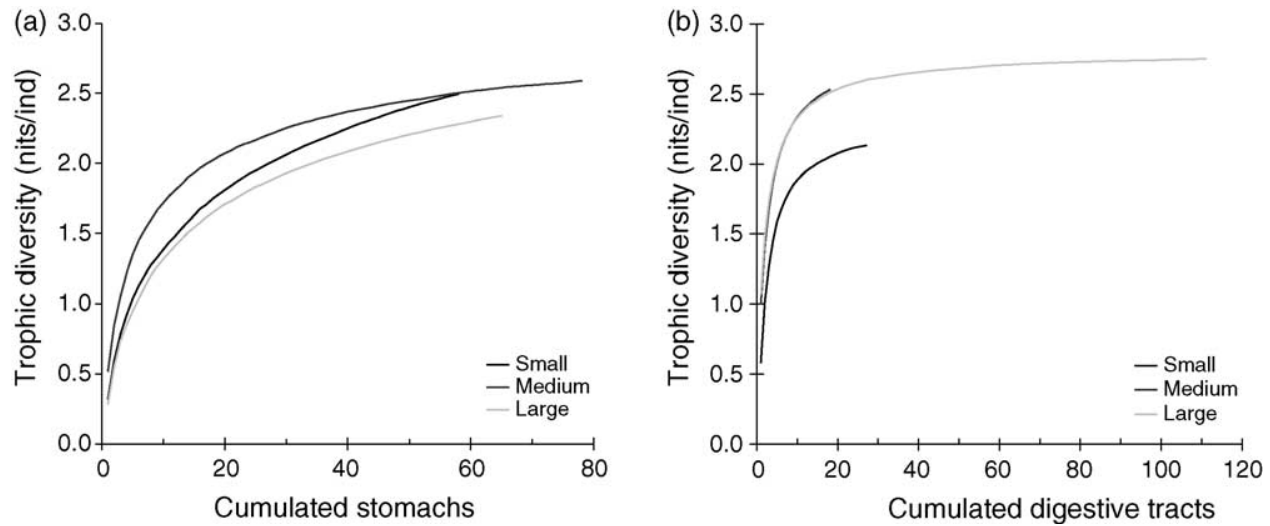

Fig. 4. Cumulative number of distinct food items for each size class. (a) white seabream, Diplodus sargus and (b) ballan wrasse, Labrus bergylta. Each graph shows the mean curve from the 1000 curves obtained for each trophic group.

ballan wrasse (Fig. 3b) it separated three groups to a dissimilarity level of 40\%: small, included individuals between 14.1 and $18.0 \mathrm{~cm} \mathrm{SL}$; medium, from 18.1 to $22.0 \mathrm{~cm} \mathrm{SL}$; and large, from 22.1 to $38.8 \mathrm{~cm} \mathrm{SL}$

The number of stomachs examined to study the ontogenetic changes in the feeding habits for both species appeared to be sufficient (Fig. 4), as all samples reached an asymptote (at least two previous values to the total sample $H^{\prime}$ were in the range $H^{\prime} \pm 0.05 H^{\prime}$.

Feeding intensity of white seabream decreased slightly with fish size from 0.36 to 0.30 (RI as \% of fish body weight) but there were no overall significant differences (Kruskal-Wallis $H_{(2,203)}=0.73 ; p=0.69$ ). The diet of small and medium size white seabreams were significantly correlated $\left(r_{\mathrm{s}}=0.53 ; p<0.05\right)$, while large individuals did not correlate with small $\left(r_{\mathrm{s}}=0.45\right.$; $p>0.05)$ or medium $\left(r_{\mathrm{s}}=0.31 ; p>0.05\right)$ size classes. Ontogenetic changes in diet composition of the white seabream are presented in Table 4. Algae were the most important food item across every size class $\left(\% R_{\mathrm{W}}>40.0\right)$, but some ontogenetic differences were observed, such as a decrease in consumption of worms,

Table 4

Ontogenetic variation in the weighted resultant index $\left(\% R_{\mathrm{W}}\right)$ for white seabream, Diplodus sargus, from the Azores $\% R_{\mathrm{W}}$

\begin{tabular}{|c|c|c|c|c|c|c|}
\hline \multirow[t]{2}{*}{ Food Items } & \multicolumn{3}{|l|}{ White Seabream } & \multicolumn{3}{|l|}{ Ballan wrasse } \\
\hline & Small 4.9-15.0 & Medium 15.1-23.0 & Large 23.1-32.9 & Small 14.1-18.0 & Medium 18.1-22.0 & Large 22.1-38.8 \\
\hline Algae & 57.08 & 43.52 & 58.32 & 1.44 & 11.04 & 5.65 \\
\hline Porifera & 0.00 & 0.20 & 4.61 & & & \\
\hline Cnidaria & 0.05 & 1.37 & 0.48 & 0.00 & 0.07 & 0.05 \\
\hline "Worms" & 22.10 & 9.91 & 1.86 & 1.16 & 6.05 & 1.23 \\
\hline Maxillopoda & 1.33 & 7.86 & 1.02 & 0.00 & 0.07 & 0.01 \\
\hline Amphipoda & 4.43 & 2.22 & 5.23 & 0.56 & 2.87 & 0.18 \\
\hline Isopoda & 0.00 & 0.15 & 0.09 & 1.88 & 1.14 & 0.02 \\
\hline Decapoda & 3.65 & 2.17 & 5.13 & 49.52 & 42.40 & 34.73 \\
\hline Gastropoda & 0.68 & 10.79 & 1.34 & 9.93 & 8.24 & 25.33 \\
\hline Bivalvia & 3.28 & 1.87 & 0.07 & 11.05 & 7.89 & 2.94 \\
\hline Echinodermata & 2.39 & 7.37 & 13.81 & 22.47 & 17.51 & 27.31 \\
\hline Pisces & 0.87 & 3.63 & 0.85 & 1.37 & 0.00 & 0.20 \\
\hline Fish Eggs & 3.82 & 3.57 & 0.94 & & & \\
\hline Tunicata & 0.00 & 4.43 & 0.15 & & & \\
\hline Miscellaneous & 0.32 & 0.94 & 6.09 & 0.63 & 2.72 & 2.33 \\
\hline$n$ & 62 & 79 & 66 & 27 & 18 & 111 \\
\hline
\end{tabular}

All size classes in $\mathrm{cm} \mathrm{SL;} n$ is the number stomachs with contents. 
bivalves and fish eggs with an increase in fish size. On the other hand, the consumption of sea-urchins considerably increased with increasing size of fish.

For ballan wrasse, feeding activity of the three size classes $(0.6 \%$ of fish body weight $)$ did not differ significantly (Kruskal-Wallis $H_{(2,156)}=0.05 ; p=0.96$ ) and the analysis of the diet composition based on aggregated categories correlated significantly between the three size classes $\left(r_{\mathrm{s}}=0.75\right.$ between small and medium size classes; $r_{\mathrm{s}}=0.79$ between small and large; $r_{\mathrm{s}}=0.87$ between medium and large; all $p<0.05)$. These results indicate no major ontogenic differences in feeding habits of ballan wrasse for the studied range. Minor changes included the decrease in predation of decapods and bivalves and an increase predation of echinoderms and gastropods with increasing fish size (Table 4).

\subsection{Diel feeding activity}

Diel feeding activity of white seabrean as described by the coefficient of vacuity and the repletion index is presented in Fig. 5. Feeding activity increased gradually after sunrise (about 7:30h), peaked from 12:30 to $16: 30 \mathrm{~h}$, and declined throughout the afternoon and evening until 7:30 h.

\subsection{Diet overlap}

Overlap between diets of the two species in the Azores was relatively low $\left(R_{\mathrm{O}}=0.27\right)$, especially for

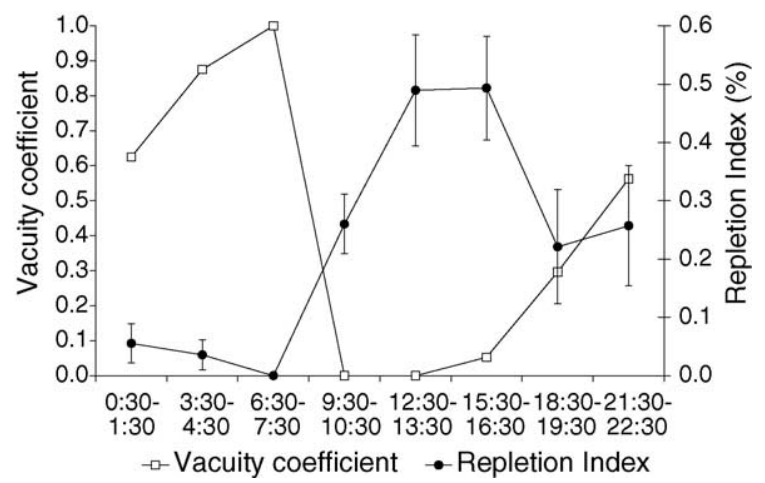

Fig. 5. Diel feeding activity of the white seabream, Diplodus sargus, as determined from changes in the mean repletion index and vacuity index. Error bars show standard error of means. Sampling intervals from 9:30 to 16:30 represent daylight hours, while all the others represent night hours.
Table 5

Schoener's diet overlap index $\left(R_{\mathrm{O}}\right)$ for white seabream, Diplodus sargus, and ballan wrasse, Labrus bergylta, of three size classes

\begin{tabular}{llll}
\hline Labrus bergylta & \multicolumn{3}{l}{ Diplodus sargus } \\
\cline { 2 - 4 } & Small & Medium & Large \\
\hline Small & 0.14 & & \\
Medium & 0.27 & 0.40 & \\
Large & 0.25 & 0.39 & 0.30 \\
\hline
\end{tabular}

smaller fish (Table 5). The highest overlaps were observed between diets of the two medium size classes $\left(R_{\mathrm{O}}=0.40\right)$ and the two large size classes $\left(R_{\mathrm{O}}=0.30\right)$.

\section{Discussion}

As general evaluation of the sample sizes, it appears that the number of stomachs examined in this study was sufficient to describe the diet for both species, including the analyses of its seasonal and ontogenetic changes. All samples reached an asymptote, because at least two previous values to the total sample trophic diversity $\left(H^{\prime}\right)$ were in the range $H^{\prime} \pm 0.05 H^{\prime}$.

\subsection{Feeding habits}

This study confirms the benthic dependence of both white seabream and ballan wrasse feeding ecology. The diet of this two species is mainly composed of benthic invertebrates of which the most important were seaurchins (A. lixula, S. granularis and P. lividus) and, in the case of ballan wrasse, decapods. In general, our results partly agree with previous works that describe the white seabream as a benthic omnivore (Joubert and Hanekon, 1980; Coetzee, 1986) and the diet of the ballan wrasse as composed mainly of molluscs and decapod crustacean (Quignard, 1966; Voss, 1975; Dipper et al., 1977; Deady and Fives, 1995). However, the great importance that echinoderms have on the diet of ballan wrasse has not been previously recorded. Furthermore, these findings confirm the hypothesis that the two species are important predators of sea-urchins and therefore highlight their potential impact in benthic shallow water communities in the Azores. Specifically, their role in controlling sea-urchins abundance and potential trophic cascade events deserves further attention. 
Algae were also found to be a major item in the diet of the white seabream. This is in accordance with other studies that extensively refer algae as food source for this species, but only Joubert and Hanekon (1980), Coetzee (1986) and Sala and Ballesteros (1997) report it as important as in our study. Seabreams may ingest algae to collect their epiphyte diatoms (Joubert and Hanekon, 1980), to extract nutrients directly from the algae (Mann and Buxton, 1992) or to optimise the digestion of animals (Lobel, 1981). Therefore, this species might also be directly affected by a negative feedback process (bottom-up) if a bloom in sea-urchins overgrazes macrophyte beds.

\subsection{Seasonal diet changes}

Feeding intensity in both species was relatively constant throughout the year. Noticeably, the slight increase observed in the feeding intensity of white seabream during the winter was most probably related to a gonadossomatic build-up need, as it coincides with the pre-spawning period of this species in the Azores (Morato et al., 2003a). Similarly, a slight increase in feeding activity of ballan wrasse was observed during pre-pawning season (unpublished data). The subsequent decrease during the spawning season may be a result of limited time availability for foraging, since during the spawning season the males of this species defend large territories where they build nests and care for the eggs (Porteiro et al., 1996).

While the diet composition of the ballan wrasse was remarkably uniform throughout the year that of the white seabream varied markedly. During summer this species feeds on algae, worms and amphipods, during autumn and winter on algae, sea-urchins and barnacles, and finally it feeds almost exclusively on algae during the spring. These results show a high trophic adaptability in the white seabream. The predation on sea-urchins, which are considered to be of low nutritional value, raises the question of why these species feed upon them on such a great amount. Noticeably, the period when urchins are of greater importance coincides with the peak of the gonadosomatic index of P. lividus in the Azores (Gonçalves, 1995). Thus, it is possible that the white seabream selectively predate sea-urchins when they are of higher nutritional value richer. Knowledge of the reproductive biology of the other sea-urchin species should cast light this suggestion.

\subsection{Ontogenetic diet shifts}

Clear ontogenetic differences in the feedings habits of both species were not observed for the fish size range considered in this study. Only the diet of larger white seabreams did not present strong correlation with the smaller size classes. In spite of the lack of statistical differences between the most size classes a consistent pattern was observed for both species. In the white seabream, there was a decrease in consumption of worms, bivalves and fish eggs, and an increase consumption of sea-urchins and decapods with the increase in fish size. Similarly, ballan wrasse showed a decrease in consumption of bivalves and decapods and an increase in echinoderms and gastropods with the increase in fish size. These results agree with the descriptions of Rosecchi (1985) for white seabream and Deady and Fives (1995) for ballan wrasse. In both cases, it is apparent that as fish grow they change from soft towards harder prey items. This is in agreement with the morphological ontogenic changes in the feeding apparatus of both species. White seabream develop numerous and larger molar teeth as it grows (Christensen, 1978; Mann and Buxton, 1992) and ballan wrasse develops pharyngeal plaques (Deady and Fives, 1995), and these changes will certainly enable the predation of larger hard-bodied prey.

\subsection{Diel feeding activity}

Diel feeding activity of white seabream increased gradually after sunrise (about 6:30h), peaked after mid-day (from 12:30 to $16: 30 \mathrm{~h}$ ) and then declined throughout the afternoon and evening until just prior to midnight. This is a typical behaviour of size-selective predators that rely mostly on visual cues (Eggers, 1977). Our analysis suggests that the white seabream is a diurnal predator, influenced by light intensity.

\subsection{Diet overlap}

Although both species feed upon similar resources, the diet overlap was relatively low. The coexistence of species within the same habitat may occur owing to different resource use. Resource partitioning may 
include food, habitat and time segregation (Pianka, 1973; Schoener, 1974; Sala and Ballesteros, 1997). Since the two species apparently fed in the same habitat and time of the day, food partitioning may display an important role in reducing competition between these bottom dwellers. This argument can be validated only with an integrated study that should include observational analysis (to examine spatial and temporal overlap) and stomach content analysis (to examine diet overlap) (Sala and Ballesteros, 1997).

\subsection{Impact of sea-urchin consumption}

Given the relative importance of sea-urchins in the diets of these two fish species, and their potential ecological role as sea-urchin population regulator, the next question is whether the fishes' impact in the sea urchin populations is significant. We estimate such impact (Table 6) using information available for $S$. granularis, a species that lives down to $60 \mathrm{~m}$ depth, and $A$. lix$u l a$, a shallower species found between 0 and $10 \mathrm{~m}$ depth (Marques, 1983). Assuming fish abundances in the Azores (unpublished data ${ }^{1}$ ), annual consumption ratios of 6.5 and $5.9 \mathrm{y}^{-1}$ for white seabream and ballan wrasse, respectively (Palomares and Pauly, 1998) and the diet composition of each predator, we estimated combined annual consumptions of $44 \mathrm{~kg} \mathrm{~km}^{-2} \mathrm{y}^{-1}$ for A. lixula, and $4 \mathrm{~kg} \mathrm{~km}^{-2} \mathrm{y}^{-1}$ for $S$. granularis. These values represent around $10 \%$ and $8 \%$ of the biomass of A. lixula and S. granularis in the area. This is to be considered as very high natural mortality caused by two predators alone, as it is reasonable to expect that other species known to consume sea-urchins (other

Table 6

Estimated annual consumption of sea-urchins by two predator fishes in the Azores

\begin{tabular}{lll}
\hline Prey/predator & \multicolumn{2}{l}{ Annual consumption $\left(\mathrm{kg} \mathrm{km}^{-2} \mathrm{y}^{-1}\right)$} \\
\cline { 2 - 3 } & Diplodus sargus & Labrus bergylta \\
\hline Arbacia lixula & $39.1(8.7 \%)$ & $5.2(1.2 \%)$ \\
Sphaerechinus granularis & $1.3(2.4 \%)$ & $2.8(5.3 \%)$ \\
Paracentrotus lividus & 0.4 & 3.3 \\
\hline
\end{tabular}

In parenthesis is the percentage of the biomass of sea-urchins consumed annually. Fish consumption per biomass per year was calculated according to the empirical regression of Palomares and Pauly (1998); fish biomass was estimated based on Afonso (2001) and Morato et al. (2001b); sea-urchins biomass was calculated according to Marques (1983) and Maciel (1998). labrid and sparid fishes, lobsters) will increase this value. Nevertheless, our estimates for A. lixula should be regarded as conservative given that we used an abundance corresponding to the maximum found in the area as well as in the Mediterranean (Sala et al., 1998b) and Madeira (Alves et al., 2001). Therefore, our results suggest that these two fish species can contribute very significantly to control sea-urchin populations in the Azores, independently of the influence of other factors such as recruitment and shelter (Sala et al., 1998b).

Nevertheless, we realize this is a simplistic assessment and stress the need to obtain estimates based in more robust data concerning sea-urchin population abundances in the region.

\section{Conclusion}

This study shows that the white seabream and the ballan wrasse are important predators of sea-urchins in Azorean coastal habitats. Furthermore, larger fish account for most of sea-urchins consumption. Thus, a reduction in the mean size of fishes, which is a typical consequence of fishing practices (Stergiou, 2002), may significantly decrease predation over sea-urchin and could thus facilitate sea-urchin proliferation. Therefore, this study suggests that fisheries regulations of Azorean costal resources should seek to maintain healthy populations of these fish species, i.e. both the population size and structure, given the need to prevent sea-urchin based cascades. It should be acknowledge that fishes, and these two species in particular, are not the only predators of sea-urchins and that sea-urchins are not the only trigger of dramatic changes in benthic communities. Other locally abundant fish species such as Coris julis and Thalassoma pavo (Sala, 1997), lobsters (Goñi et al., 2001; Shears and Babcock, 2002), other large crustaceans and starfish (Sala et al., 1998a) are also known for predating sea-urchins elsewhere, thus deserving further attention. This strongly suggests that a further effort to identify other sea-urchin predators and scavengers on dead sea-urchins should be put in place as well as in situ experimental studies to assess the degree of herbivory by sea-urchins and consequences for the biotopes. This information should then be used in the development and improvement of ecosystem models for the Azores coastal habitats 
(Guénette and Morato, 2001) in order to verify the mixed trophic impacts in the ecosystem.

\section{Acknowledgments}

Financial support for this study was given by the Portuguese National Science Foundation (FCT) through the PRAXIS/3/3.2/EMG/1957/95 project, and PRAXIS grants BIC/1938/96 to TM and BIC/1930/96 to PA. The authors which to thank several volunteers for help in data collection, namely Norberto Serpa, Victor Rosa, José Branco, Frederico Cardigos, Jorge Fontes, Filipa Gomes, Carmelina Leal, Miguel Machete, Fátima Mendes and Fernando Tempera. Thanks are also due to Sérgio Ávila, João Gonçalves and Peter Wirtz for helping with the identification of stomach contents.

\section{Appendix A. Supplementary data}

Supplementary data associated with this article can be found, in the online version, at doi:10.1016/ j.fishres.2005.04.013.

\section{References}

Afonso, P., 2001. Padrões espaciais na estrutura da comunidade de peixes costeiros dos Açores. Master Thesis, Universidade de Coimbra, Portugal.

Alonso, M.K., Crespo, E.A., García, N.A., Pedraza, S.N., Mariotti, P.A., Morac, N.J., 2002. Fishery and ontogenetic driven changes in the diet of the spiny dogfish, Squalus acanthias, in Patagonian waters, Argentina. Environ. Biol. Fish. 63, 193-202.

Alves, F.M.A., Chícharo, L.M., Serrão, E., Abreu, A.D., 2001. Algal cover and sea urchin spatial distribution at Madeira Island (NE Atlantic). Sci. Mar. (Barc.) 65, 383-392.

Briggs, J.C., 1995. Global Biogeography. Elsevier, Amsterdam.

Christensen, M.S., 1978. Trophic relationships in juveniles of three species of sparid fishes in the South African marine littoral. Fish. Bull. 76, 389-401.

Coetzee, P.S., 1986. Diet composition and breeding cycle of blacktail, Diplodus sargus capensis (Pisces: Sparidae), caught off St. Croix Island, Algoa Bay, South Africa. S. Afr. J. Zool. 21, 237-243.

Cortés, E., 1997. A critical review of methods of studying fish feeding based on analysis of stomach contents: application to elasmobranch fishes. Can. J. Fish. Aquat. Sci. 54, 726-738.

Deady, S., Fives, J.M., 1995. Diet of Ballan Wrasse, Labrus bergylta, and some comparisons with the diet of Corking Wrasse, Crenilabrus melops. J. Mar. Biol. Assoc. UK 75, 651-665.
Dipper, F.A., Bridges, C.R., Menz, A., 1977. Age, growth and feeding in the ballan wrasse, Labrus bergylta Ascanius (1767). J. Fish. Biol. 11, 105-200.

Eggers, D.M., 1977. Factors in interpreting data obtained by diel sampling of fish stomachs. J. Fish. Res. Board Can. 34, 290-294.

Estes, J.A., Duggins, D.O., 1995. Sea otters and kelp forests in Alaska: generality and variation in a community ecological paradigm. Ecol. Monogr. 65, 75-100.

Ferry, L.A., Cailliet, G.M., 1996. Sample size and data analysis: are we characterizing and comparing diet properly? In: MacKinley, D., Shearer, K. (Eds.), GUTSHOP '96. Feeding Ecology and Nutrition in Fish: Symposium Proceedings. American Fisheries Society, San Francisco.

Fontes, J., Machete, M., Santos, R.S., 2002. Projecto BARCA. Bases para a caracterização de duas pescarias artesanais costeiras dos Açores: redes de emalhar e peixe-porco: Relatório Final. Arquivos do DOP, Série Estudos 6/2002.

Fritz, E.S., 1974. Total diet comparison in fishes by Spearman Rank correlation coefficients. Copeia 1, 210-214.

Gonçalves, J.M., 1995. Aspectos da Biologia e Potencialidades da Exploração de Ouriços-do-Mar (Sphaerechinus granularis) nos Açores. Relatório da $13^{\mathrm{a}}$ Semana das Pescas, 1994, Horta.

Goñi, R., Quetglas, A., Reñones, O., 2001. Diet of spiny lobster Palinurus elephas (Decapoda: Palinuridae) from the Columbretes Islands marine reserve (north-western Mediterranean). J. Mar. Biol. Assoc. UK 81, 347-348.

Guénette, S., Morato, T., 2001. The Azores archipelago in 1997. In: Guénette, S., Christensen, V., Pauly, D. (Eds.), Fisheries Impacts on North Atlantic Ecosystems: Models and Analyses. Fisheries Centre Research Reports 9(4), University of British Columbia, Vancouver.

Hurtubia, J., 1973. Trophic diversity measurement in sympatric predatory species. Ecology 19, 36-58.

Joubert, C.S.W., Hanekon, P.B., 1980. A study of feeding in some inshore reef fish of the Natal Coast, South Africa. S. Afr. J. Zool. $15,262-274$.

Lobel, P.S., 1981. Trophic biology of herbivorous reef fishes: alimentary $\mathrm{pH}$ and digestive capabilities. J. Fish. Biol. 19, 365397.

Lloris, D., Rucabado, J., Figueroa, H., 1991. Biogeography of the Macaronesian ichthyofauna. Bol. Mus. Munic. Funchal 43, 191-241.

Maciel, P.S., 1998. Distribuição dos ouríços-do-mar de espinhos curtos Sphaerechinus granularis na costa da ilha do Faial, Açores. Licenciatura Thesis. Universidade dos Açores, Portugal.

Magurran, A.E., 1988. Ecological Diversity and its Measurements. Princeton University Press, Princeton.

Mann, B.Q., Buxton, C.D., 1992. Diets of Diplodus sargus capensis and D. cervinus hottentotus (Pisces: Sparidae) on the Tsitsikamma coast, South Africa. Koedoe 35, 27-36.

Marques, V.M., 1983. Peuplements benthiques de Açores; 1 - echinoderms. Arq. Mus. Bocage AII (I), 1-7.

McClanahan, T.R., Sala, E., 1997. A Mediterranean rocky bottom ecosystem fisheries model. Ecol. Model. 104, 145-164.

Michel, C., Lejeune, P., Voss, J., 1987. Biologie et comportement des Labridés européens (labres, crénilabres, rouquiers, vieilles et girelles). Rev. Fr. Aquariol. 14, 1-80. 
Mohan, M.V., Sankaran, T.M., 1988. Two new indices for stomach content analysis of fishes. J. Fish. Biol. 33, 289-292.

Morato, T., Solà, E., Grós, M.P., Menezes, G., 2001a. Feeding habits of two congener species of seabreams, Pagellus bogaraveo and Pagellus acarne, off the Azores (northeastern Atlantic) during spring of 1996 and 1997. Bull. Mar. Sci. 69, 1073-1087.

Morato, T., Afonso, P., Lourinho, P., Barreiros, J.P., Santos, R.S., Nash, R.D.M., 2001b. Weight-length relationships for 21 coastal fish species of the Azores, northeastern Atlantic. Fish. Res. 50, 297-302.

Morato, T., Afonso, P., Lourinho, P., Nash, R.D.M., Santos, R.S., 2003a. Reproductive biology and recruitment of the white sea bream in the Azores. J. Fish. Biol. 63, 59-72.

Morato, T., Solà, E., Grós, M.P., Menezes, G., 2003b. Diets of thornback ray (Raja clavata) and tope shark (Galeorhinus galeus) in the bottom longline fishery of the Azores, northeastern Atlantic. Fish. Bull. 101, 509-602.

Palomares, M.L.D., Pauly, D., 1998. Predicting food consumption of fish populations as functions of mortality, food type, morphometrics, temperature and salinity. Mar. Freshwater Res. 49, 447-453.

Pianka, E.R., 1973. The structure of lizard communities. Annu. Rev. Ecol. Syst. 21, 213-220.

Pielou, E.C., 1966. The measurement of diversity in different types of biological collections. J. Theor. Biol. 13, 131-144.

Pierce, G.J., Boyle, P.R., 1991. A review of methods for diet analysis in piscivorous marine mammals. Oceanogr. Mar. Biol. Annu. Rev. 29, 409-486.

Pinnegar, J.K., Polunin, N.V.C., Francour, P., Badalamenti, F., Chemello, R., Harmelin-Vivien, M.-L., Hereu, B., Milazzo, M., Zabala, M., D’Anna, G., Pipitone, C., 2000. Trophic cascades in benthic marine ecosystems: lessons for fisheries and protected-area management. Environ. Conserv. 27, 179200.

Polis, G.A., Sears, A.L.W., Huxel, G.R., Strong, D.R., Maron, J., 2000. When is a trophic cascade a trophic cascade? Trends Ecol. Evol. 15, 473-475.

Porteiro, F.M., Barreiros, J.P., Santos, R.S., 1996. Wrasses (Teleostei: Labridae) of the Azores. Arquipélago (Life Mar. Sci.) 14A, 23-40.

Quignard, J.P., 1966. Recherches sur les Labridae (Poissons Téléostéens Perciformes) des côtes européenes-systématique et biologie. Nat. Monspeliensia Sér. Zool. 5, 7-248.
Rosecchi, E., 1985. L'alimentation de Diplodus sargus, Diplodus vulgaris et Sparus aurata (Pisces, Sparidae) dans le Golfe du Lion et les lagunes littorals. Revue de Travaux de l'Institut de Pêches Maritimes 49, 125-141.

Sala, E., 1997. Fish predators and scavengers of the sea urchin Paracentrotus lividus in protected areas of the north-west Mediterranean Sea. Mar. Biol. 129, 531-539.

Sala, E., Zabala, M., 1996. Fish predation and the structure of the sea urchin Paracentrotus lividus populations in the NW Mediterranean. Mar. Ecol. Prog. Ser. 140, 71-81.

Sala, E., Ballesteros, E., 1997. Partitioning of space and food resources by three fish of the genus Diplodus (Sparidae) in a Mediterranean rocky infralittoral ecosystem. Mar. Ecol. Prog. Ser. 152, 273-283.

Sala, E., Boudouresque, C.F., Harmelin-Vivien, M., 1998a. Fishing, trophic cascades, and the structure of algal assemblages: evaluation of an old but untested paradigm. Oikos 82, 425-439.

Sala, E., Ribes, M., Hereu, B., Zabala, M., Alva, V., Coma, R., Garrabou, J., 1998b. Temporal variability in abundance of the sea urchins Paracentrotus lividus and Arbacia lixula in the northwestern Mediterranean: comparison between a marine reserve and an unprotected area. Mar. Ecol. Prog. Ser. 168, 135-145.

Santos, R.S., Hawkins, S., Monteiro, L.R., Alves, M., Isidro, E.J., 1995. Case studies and reviews. Marine research, resources and conservation in the Azores. Aquat. Conserv.: Mar. Freshwater Ecosyst. 5, 311-354.

Schoener, T.W., 1970. Nonsynchronous spatial overlap of lizards in patchy habitats. Ecology 51, 408-418.

Schoener, T.W., 1974. Resources partitioning in natural communities. Science 185, 27-39.

Shears, N.T., Babcock, R.C., 2002. Marine reserves demonstrate top-down control of community structure on temperate reefs. Oecologia 132, 131-142.

Shears, N.T., Babcock, R.C., 2003. Continuing trophic cascade effects after 25 years of no-take marine reserve protection. Mar. Ecol. Prog. Ser. 246, 1-16.

Stergiou, K.I., 2002. Overfishing, tropicalization of fish stocks, uncertainty and ecosystem management: resharpening Ockham's razor. Fish. Res. 55, 1-9.

Voss, J., 1975. A propos de quelques poissons de la Mediterranée. Xyrichthis novacula L., Labrus merula L., Labrus bergylta Ascanius. Rev. Fr. Aquariol. 2, 17-20.

Zar, J.H., 1996. Biostatistical Analysis. Prentice Hall, New Jersey. 